\title{
Can We Make Sense of "Neutrality" In the Religion Clause Cases?: Seven Rescue Attempts ANd a Viable Alternative
}

\author{
R. George Wright*
}

\section{TABLE OF CONTENTS}

I. INTRODUCTION ............................. 878

II. USING NEUTRALITY IN RELIGION CLAUSE

CASES .................................. 882

III. THE SCHOLARS ON THE IDEA OF NEUTRALITY.. 889

A. The Religion Clause Context in Particular .... 889

B. Is the Legal Scholarship on Neutrality Beyond the Religion Clause Context of Any AssisTANCE? ............................ 893

IV. WHAT COULD RELIGION CLAUSE NEUTRALITY POSSIBLY AMOUNT TO?....................... 895

A. Unfazed Optimism: Perhaps Something Will Yet Turn UP................................. 896

B. The Possible Special Judicial Manipulability of NeutraltTy .................................. 896

C. The Essential Contestability of Neutrality .... 897

D. Neutrality As a Legal Fiction ................. 899

E. Neutrality and the Analogy to Moral
Fictionalism ................................... 900

F. Neutrality and the Analogy to Moral "Error THEORY" ................................. 902

G. Shrinking the Universe of Relevant Test Cases: Could Courts Just Lower the Bar for Religious Neutrality? ......................... 904

V. CONCLUSION: AFTER "NEUTRALITY," A SURPRISING ALTERNATIVE 905

\section{ABSTRACT}

The idea of neutrality is central to many Establishment Clause and Free Exercise Clause cases (Religion Clause cases). A number of these Religion

* Lawrence A. Jegen Professor of Law, Indiana University Robert H. McKinney School of Law. The author's thanks are hereby extended to Angela M. Stackhouse and Samantha S. Everett. 
Clause cases do not refer explicitly to neutrality but instead refer to closely related ideas. These neutrality-related ideas include non-sectarianism, nondenominationalism, broad inclusivity, broad ecumenism, non-indoctrination, non-proselytization, non-divisiveness and even, in language suggestive of equal protection, non-discrimination. This Article explores both neutrality and those related ideas, which share the problems associated with the underlying idea of religious neutrality.

This Article concludes that neutrality and related ideas are not generally used in a coherent, workable, and reasonably persuasive way in Religion Clause cases. Examining seven alternative uses, functions, and interpretations of religious neutrality provides a better understanding why Religion Clause neutrality retains its prominence. But in the end, considering all the alternative approaches, alone or in combination, there is no genuinely workable, coherent, and reasonably attractive view of neutrality. Ultimately, one or more separate goals, standards, or criteria must be invoked to replace neutrality if our Religion Clause jurisprudence is to be as legitimate as possible. Religious neutrality is not an achievable goal.

\section{INTRODUCTION}

$\mathrm{T}$ THE idea of neutrality is central to many Establishment Clause ${ }^{1}$ and Free Exercise Clause ${ }^{2}$ cases (Religion Clause cases). A number of these Religion Clause cases do not refer explicitly to neu-

1. See, e.g., Arnold H. Loewy, The Positive Reality and Normative Virtues of a "Neutral" Establishment Clause, 41 BRANDEIs L.J. 533, 533 (2003) ("Establishment Clause cases are typically animated by . . . separation, accommodation, and neutrality."). Professor Loewy finds that generally, "the Court is moving towards neutrality as its presumptive standard," and that "this is a good thing and probably should be accelerated." Id. at 533-34; see also Gabriel A. Moens, The Menace of Neutrality in Religion, 2004 BYU L. REv. 535, 536 ("The Supreme Court has interpreted the Establishment Clause as requiring or involving the application of the neutrality principle. This principle imposes an obligation on federal and state governments to refrain from favoring or disfavoring either sectarianism or secularism.").

As for the case law itself, neutrality considerations are prominent. Consider the following sampling of recent "neutralist" Establishment Clause cases, beginning with cases involving local government board or commission invocations. See, e.g., Galloway v. Town of Greece, 681 F.3d 20, 31-34 (2d Cir. 2012) (requiring an invocation selection process that is "substantially neutral among[st] creeds," and an overall practice, as determined under the totality of the circumstances and as judged by a reasonable observer, to involve no official favoritism, disparagement, advancement, proselytization, official affiliation, or differing degrees of official acceptance); Joyner v. Forsyth Cnty., 653 F.3d 341, 342-43 (4th Cir. 2011); Pelphrey v. Cobb Cnty., 547 F.3d 1263, 1273-74 (11th Cir. 2008); Turner v. City Council, 534 F.3d 352, 355-56 (4th Cir. 2008); Hinrichs v. Bosma, 440 F.3d 393, 398-400 (7th Cir. 2006), dismissed for lack of standing sub nom. Hinrichs v. Speaker of the House of Representatives of the Ind. Gen. Assembly, 506 F.3d 584 (7th Cir. 2007); Wynne v. Town of Great Falls, 376 F.3d 292, 300-01 (4th Cir. 2004); Rubin v. City of Lancaster, 802 F. Supp. 2d 1107, 1113-15 (C.D. Cal. 2011).

Many of these cases seek, among other aims, to determine the proper role of the concern for indoctrination and sectarianism in state legislature invocations. That concern was expressed, apparently with some ambiguity, in Marsh v. Chambers, 463 U.S. 783, 792-95 (1983). 
trality but instead refer to closely related ideas. These neutrality-related ideas include non-sectarianism, non-denominationalism, broad inclusivity, broad ecumenism, non-indoctrination, non-proselytization, non-divisiveness, and even, in language suggestive of equal protection, non-

For concern over neutrality and related ideas in the somewhat different context of invocations at public school board meetings, see, for example, Doe v. Tangipahoa Parish School Board, 473 F.3d 188, 202-03 (5th Cir. 2006), vacated for lack of standing, 494 F.3d 494 (5th Cir. 2007) (en banc); Doe \#2 v. Tangipahoa Parish School Board, 631 F. Supp. 2d 823, 839-40 (E.D. La. 2009). But see Coles ex rel. Coles v. Cleveland Bd. of Educ., 171 F.3d 369, 386-89 (6th Cir. 1999) (focusing less on neutrality than on coercion and endorsement, as in some school prayer cases, including, for example, Doe v. Indian River Sch. Dist., 653 F.3d 256, 275-78 (3d Cir. 2011)).

Neutrality has also been a central inquiry in a number of the public school moment-ofsilence and related cases. See, e.g., Holloman v. Harland, 370 F.3d 1252, 1286-88 (11th Cir. 2004); Mellen v. Bunting, 327 F.3d 355, 374-75 (4th Cir. 2003); Wallace v. Jaffree, 472 U.S. 38, 60 \& n.50 (1985) (citing Stone v. Graham, 449 U.S. 39, 42 (1980)); Comm. for Pub. Educ. \& Religious Liberty v. Nyquist, 413 U.S. 756, 792-93 (1973); Epperson v. Arkansas, 393 U.S. 97, 109 (1968)). Even the major recent school prayer cases express some degree of concern for neutrality and closely related ideas. See, e.g., Santa Fe Indep. Sch. Dist. v. Doe, 530 U.S. 290,307 n.21 (2000); Lee v. Weisman, 505 U.S. 577, 587-88 (1992).

In the cases addressing school vouchers, tax deductions, and federal financial assistance to religious schools among others, concerns for neutrality and similar ideas arise. See, e.g., Zelman v. Simmons-Harris, 536 U.S. 639, 649-55 (2002); Mueller v. Allen, 463 U.S. 388, 398-401 (1983); Mueller, 463 U.S. at 404 (Marshall, J., dissenting); Winn v. Ariz. Christian Sch. Tuition Org., 586 F.3d 649, 650, 652-56 (9th Cir. 2009) (Nelson, J., concurring), rev'd for lack of standing, $131 \mathrm{~S}$. Ct. 1436 (2011).

Among the cases not readily falling into any of the above categories, similar neutrality concerns are expressed in, for example, Rosenberger v. Rector \& Visitors, 515 U.S. 819, 839-42 (1995) (public university subsidy of religious student group); Johnson v. Poway Unified School District, 658 F.3d 954, 971-72 (9th Cir. 2011) (public school's removal of teacher's religious banners from classroom); Bronx Household of Faith $v$. Board of Education, 650 F.3d 30, 42-44 (2d Cir. 2011) (use of public school by outside group for religious worship services on Sundays); Trunk v. City of San Diego, 629 F.3d 1099, 1105-06 (9th Cir. 2011) (war memorial with Latin Cross on federal land); Newdow v. Roberts, 603 F.3d 1002 , 1017-21 (D.C. Cir. 2010) (religious element of presidential inaugural oath); Green v. Haskell County Board of Commissioners, 568 F.3d 784, 802-04 (10th Cir. 2009) (Ten Commandments monument on courthouse lawn); Doe v. Beaumont Independent School District, 240 F.3d 462, 464, 470-71 (5th Cir. 2001) (en banc) ("clergy in schools" volunteer student counseling program); Columbia Union College v. Clarke, 159 F.3d 151, 169 (4th Cir. 1998); Clarke, 159 F.3d at 171-72 (Wilkinson, J., dissenting) (state funding of general education programs at "pervasively sectarian" college); and Wirtz v. City of South Bend, 669 F.3d 860, 861 (7th Cir. 2012) (city's purchase of real property for benefit of a religious school).

2. A judicial focus on neutrality and related concepts is also central to a number of the major cases in the area of the free exercise of religion. Perhaps the best known of these is Employment Division, Department of Human Resources v. Smith, 494 U.S. 872, 879 (1990). See id. at 891, 901 (O'Connor, J., concurring) (religious use of peyote in an unemployment compensation benefits case); see also, e.g., Freedom From Religion Found. v. Hanover Sch. Dist., 626 F.3d 1, 12 (1st Cir. 2010) (sectarianism and secularity in a Pledge of Allegiance Free Exercise case); Gonzales v. O Centro Espirita Beneficente Uniao do Vegetal, 546 U.S. 418, 439 (2006) (religious group's use of hallucinogenic tea); Cutter v. Wilkinson, 544 U.S. 709, 719-20 (2005) (Establishment Clause case citing a prior free exercise of religion case); City of Boerne v. Flores, 521 U.S. 507, 513-14 (1997) (reaffirming the Smith standard, supra); Bd. of Educ. v. Grumet, 512 U.S. 687, 696 (1994) (Establishment Clause case addressing the role of "neutrality" under both the Establishment Clause and the Free Exercise Clause); Church of Lukumi Babalu Aye, Inc. v. City of Hialeah, 508 U.S. 520, 531-42 (1993) (religiously motivated ritual animal slaughter) (distinguishing several forms of neutrality). 
discrimination. ${ }^{3}$ This Article explores both neutrality and those related ideas, which share the problems associated with the underlying idea of religious neutrality.

The frequency and importance of references to neutrality and related ideas in Free Exercise and Establishment Clause jurisprudence does not show, however, that "neutrality" is typically used in any genuinely coherent, workable, and reasonably persuasive sense. It is, in fact, far from obvious that the cases use the term "neutrality" coherently. On the actual coherence of the idea of Religion Clause neutrality, reasonable minds could differ. ${ }^{4}$

This Article sorts out various ideas of neutrality and finds that Religion Clause neutrality, as typically phrased, lacks coherence. ${ }^{5}$ But the Article does not simply discard the idea of Religion Clause neutrality. Instead, the Article explores seven separate, alternative ways of thinking about Religion Clause neutrality and considers their respective appeal and .defects. ${ }^{6}$

At this introductory point, these seven ways of thinking about neutrality in the Religion Clause cases can be listed without much clarification or elaboration. First, and most straightforwardly, some would argue ${ }^{7}$ that some identifiable, intended, coherent, workable, and reasonably attractive idea of neutrality can be identified that can tie together, in some recognizable way, the relevant Religion Clause cases. ${ }^{8}$ Unfortunately, our analysis is unable to identify any such sense and must press on.

Second, and now assuming the unavailability of any commonly recognized idea of neutrality meeting the above criteria, this Article considers whether Religion Clause neutrality is a judicial tool of manipulation. ${ }^{9}$ This may be a feature for some-but this possibility hardly seems to promote the broader public interest. Other, more legitimate reasons for continuing to rely on the idea of neutrality are then explored..$^{10}$

Third, this Article considers the possibility that the courts, whether or not they recognize what they are doing, may in fact be taking advantage of what has been called the "essentially contested"11 nature of the concept of Religion Clause neutrality. This Article explains "essential contestability" and how the essential contestedness of "neutrality" might help account for its continuing prominent use. ${ }^{12}$ This approach is also

3. These ideas are referred to frequently throughout the Establishment Clause and Free Exercise Clause cases cited supra notes 1 and 2, respectively. For a discussion of neutrality as non-discrimination in particular, see, for example, Frederick Mark Gedicks, Religious Exemptions, Formal Neutrality, and Laïcité, 13 InD. J. Global LeGal STud. 473, 485-90 (2006).

4. For opposing conclusions on this issue, see infra Part III.A.

5. See infra Parts II-III.

6. See infra Part IV.

7. See infra Part III.A.

8. See infra Part IV.A.

9. See discussion infra Part IV.B.

10. See discussion infra Part IV.B.

11. See infra Part IV.C.

12. See infra Part IV.C. 
hardly without its limits and costs.

Fourth, this Article considers the possibility that, whether or not the courts recognize it, the idea of neutrality in the Religion Clause cases operates as what Lon Fuller ${ }^{13}$ classically referred to as a legal fiction. ${ }^{14}$ This Article considers the costs and benefits of thinking of religious neutrality as a legal fiction.

Fifth, this Article considers the possibility that neutrality and related terms, likely without judicial intent, can be interpreted along lines analogous to what some contemporary philosophers refer to as "moral fictionalism." 15 As applied in its original moral context, and by analogy in our own specific case law context, the moral fictionalist approach is elaborated on and then critiqued. ${ }^{16}$

The sixth possibility is especially related to the fifth. This sixth possibility is also most plausibly thought of as an interpretation that does not reflect the intent of the judges deploying the idea of neutrality in Religion Clause contexts. This possibility draws by analogy on what has been called "error theory" in ethics. ${ }^{17}$ Here, the Article considers an "error theory" use of neutrality in Religion Clause cases and then critiques error theory, as applied by analogy, in the Religion Clause context. ${ }^{18}$

Finally, and related to the fifth and sixth approaches, the seventh possibility considers, by analogy to some contemporary philosophical works, whether it would be legitimate and helpful to eliminate some possible test cases that apply the idea of neutrality in the Religion Clause context. ${ }^{19}$ This idea, which this Article critiques, basically argues that it is justifiable to "lower the bar" in deciding what should count as neutral.

This Article concludes that neutrality and related ideas are not generally used in a coherent, workable, and reasonably persuasive way in $\mathrm{Re}$ ligion Clause cases. ${ }^{20}$ Examining seven alternative uses, functions, and interpretations of religious neutrality provides a better understanding of why Religion Clause neutrality retains its prominence. But in the end, considering all the alternative approaches, alone or in combination, there is no genuinely workable, coherent, and reasonably attractive view of neutrality. Ultimately, one or more separate goals, standards, or criteria must be invoked to replace neutrality if our Religion Clause jurisprudence is to be as legitimate as possible. Religious neutrality is not an achievable goal.

The Conclusion briefly explores the surprisingly useful analogy to cases that distinguish police power regulations from compensable takings, in which some strikingly similar policy issues arise. Though it may initially

\footnotetext{
13. See infra note 124 and accompanying text.

14. See discussion infra Part IV.D.

15. See infra Part IV.E.

16. See infra Part IV.E.

17. See infra Part IV.F.

18. See infra Part IV.F.

19. See infra Part IV.G.

20. See infra Part V.
} 
seem far removed from the Religion Clause cases, the analogy could offer valuable guidance to courts considering Religion Clause issues.

\section{USING NEUTRALITY IN RELIGION CLAUSE CASES}

The idea of neutrality and related concepts is conspicuous throughout the contemporary Religion Clause case law. That is not to say that it dominates the analysis in the major cases. ${ }^{21}$ Nevertheless, neutrality is prominent. ${ }^{22}$

Consider, for example, Wallace v. Jaffree, an Establishment Clause case that involves a law authorizing public school moments of silence for prayer meditation. ${ }^{23}$ In Jaffree, the Court stated unequivocally that the law is "not consistent with the established principle that the government must pursue a course of complete neutrality toward religion." 24 The Court therefore construed, perhaps unjustifiably, neutrality with striking breadth. ${ }^{25}$

More recently, in the context of local board of commissioners' public meetings, Judge Wilkinson of the Fourth Circuit elaborated on the neutrality theme:

[I]nvocations must consist of the type of nonsectarian prayers that solemnize the legislative task and seek to unite rather than divide. Sectarian prayers must not serve as the gateway to citizen participation in the affairs of local government. To have them do so runs afoul of the promise of public neutrality among faiths that resides at the heart of the First Amendment's religion clauses. ${ }^{26}$

Of course, the asserted neutrality must encompass not just all religions, but also irreligions. ${ }^{27}$

21. Consider, for example, the role of coercion in school prayer cases including Santa Fe Independent School District v. Doe, 530 U.S. 290, 306-07 (2000), and Lee v. Weisman, 505 U.S. 577, 587 (1992). For a recent critique of coercion as used in Religion Clause jurisprudence, see R. George Wright, Why a Coercion Test Is of No Use in Establishment Clause Cases, 41 Cumb. L. Rev. 193, 193-95 (2010-2011).

22. See, e.g., cases cited supra notes 1-2. Nor is neutrality's prominence confined to United States jurisprudence. For international examples, see Rafael Palomino, Religion and Neutrality: Myth, Principle, and Meaning, 2011 BYU L. Rev. 657, 658-59 (2011).

23. 472 U.S. $38,59-60(1985)$.

24. Id. at 60 (emphasis added). Justice Stevens cited seven Supreme Court cases for this proposition. See id. at 60 n. 50 ; Kent Greenawalt, Teaching About Religion in the Public Schools, 18 J.L. \& Pol. 329, 329-31, 366-70 (2002) (discussing the case law).

25. For discussion on an expansive constitutional role for government accommodation of religious practices and beliefs, see, for example, Michael W. McConnell, Accommodation of Religion: An Update and a Response to Critics, 60 GEO. WASH. L. REv. 685 (1992).

26. Joyner v. Forsyth Cnty., 653 F.3d 341, 342-43 (4th Cir. 2011).

27. See, e.g., McCreary Cnty. v. ACLU, 545 U.S. 844, 860 (2005); Mitchell v. Helms, 530 U.S. 793,878 (2000) (Souter, J., dissenting) (neutrality as "equipoise" or "evenhandedness"); Lemon v. Kurtzman, 403 U.S. 602, 612 (1971) (The regulation's "principal or primary effect must be one that neither advances nor inhibits religion."); Epperson v. Arkansas, 393 U.S. 97, 103-04 (1968) ("Government . . . must be neutral in matters of religious theory, doctrine, and practice. It may not be hostile to any religion or to the advocacy of no-religion; and it may not aid, foster, or promote one religion or religious theory against another or even against the militant opposite. The First Amendment mandates governmental neutrality between religion and religion, and between religion and 
This constitutionally sought after conception of neutrality seeks to avoid what the cases refer to as sectarianism, denominational advancement, exclusivity, intolerance, favoritism, non-ecumenism, indoctrination, proselytization, divisiveness, discrimination, or religious marginalization. ${ }^{28}$ The rationale underlying each of these aims, if there is one, is a social ideal "that those [persons] of different creeds are in the end kindred spirits." 29 Or one could say, a bit more technically, that the neutrality cases try to universalize a familiar, but unfortunately not universally shared, form of what we might choose to call a broad, Lockean liberalism. ${ }^{30}$ Let us now consider some of the problems of Religion Clause neutrality.

The cases actually show that judges are aware of some of the complications of neutrality. The courts are aware, for example, that a policy's "facial" or "formal" neutrality may mask the policy's non-neutral effects, intended or not, in the real world. ${ }^{31}$ In Free Exercise Clause jurisprudence, moreover, it is widely appreciated that "laws 'neutral' toward religion may burden religious exercise as surely as laws intended to interfere with religious exercise." 32

But the courts do not always press their inquiry into the predictable effects of "facially neutral" statutes. Consider the summary language

nonreligion [sic]."); see also Morgan v. Swanson, 659 F.3d 359, 411 n.27 (5th Cir. 2011) (en banc); Comer v. Scott, 610 F.3d 929, 933 (5th Cir. 2010) (quoting Epperson, 393 U.S. at 103-04); Holloman ex rel. Hollman v. Harland, 370 F.3d 1252, 1288 (11th Cir. 2004) (quoting Mitchell, 530 U.S. at 878).

28. For the sake of convenience, the reader's attention is directed to Joyner, $653 \mathrm{~F} .3 \mathrm{~d}$ at $342-43$, in which nearly all of these conceptions are referred to with further citations.

29. Joyner, 653 F.3d at 347 . Note that any supposed benevolence toward any religion or nonbelief that assigns its own adherents a special and distinct position is inherently not neutral. Among contemporary Americans, religions differ significantly in the extent to which their adherents believe that they embrace "the one, true faith leading to eternal life." See Pew Forum on Religion and Public Life, U.S. Religious Landscape SurvEY 174 (2008), available at http://www.religions.pewforum.org/report-religion-landscapestudy-full.pdf (last visited Nov. 16, 2012).

30. By "Lockean liberalism" I refer to the spirit underlying John Locke's letters on toleration. See Locke On Toleration 3 (Richard Vernon ed., Michael Silverthorne trans., Cambridge Univ. Press 2010) (1689); John Locke, A LetTer Concerning TolerATION: IN Focus 16-19, 36 (John Horton \& Susan Mendus eds., 1991) (with accompanying critical essays). For some limits on toleration suggested by Locke, see id. at 46-47. For a broader context, see John Locke, Of Civil Government: Second Treatise 2-3 (Henry Regnery Co. 1955) (1690). For a later development in this Lockean liberal project, see Gotthold Ephraim Lessing, Nathan the Wise act 3, sc. 2 (William Taylor trans., Cassel \& Co. 1893) (1779), available at http://www.gutenberg.org/cache/epub/3820/pg3820. html (last visited Nov. 13, 2011) (emphasizing inter-religious ecumenism, if not syncretism). For an anticipation of Lockean liberalism confined to the religious sphere, and even then within stark limits, see Thomas More, Utopia 72-81 (Robert M. Adams ed. \& trans., Norton 2d ed. 1992) (1516).

31. See Santa Fe Indep. Sch. Dist. v. Doe, 530 U.S. 290,307 n. 21 (2000) ("Even if the plain language of the [school invocation] policy were facially neutral, 'the Establishment Clause forbids a State to hide behind the application of formally neutral criteria and remain studiously oblivious to the effects of its actions.'") (quoting Capital Square Review \& Advisory Bd. v. Pinette, 515 U.S. 753, 777 (1995) (O'Connor, J., concurring)).

32. Gonzales v. O Centro Espirita Beneficente Uniao do Vegetal, 546 U.S. 418, 439 (2006). 
from the school voucher Establishment Clause case of Zelman v. Simmons-Harris:

[W] here a government aid program is neutral with respect to religion, and provides assistance directly to a broad class of citizens who, in turn, direct government aid to religious schools wholly as a result of their own genuine and independent private choice, the program is not readily subject to challenge under the Establishment Clause. ${ }^{33}$

There is doubtless a loose, formalistic sense in which one might call any such school voucher program religiously neutral. But, in all relevant respects characterizing such a program as substantially neutral, or as "close" to neutral as may be practical, is simply implausible.

What if, for example, it is predictable, or turns out to be the case, that despite the formal neutrality and the parents' intervening choices nearly all the financial benefit of the program accrues to religious schools, perhaps of a particular religious denomination, rather than to secular public or private schools? ${ }^{34}$ How do we know that such predictable and substantial non-neutrality leaves Establishment Clause neutrality untouched?

Or what if it turned out that most of the funds went to public and other nonreligious schools, but that even the lower level of funding eventually accruing to religious schools triggered a mass exodus of students from the public schools into sectarian schools? Perhaps a portion of public school parents need only a minimal financial incentive to fulfill their desire to leave the public school system.

On the other hand, what if over time many religious schools became financially dependent on school voucher funding, with various nondiscrimination requirements gradually being attached such that the religious schools' doctrinal messages became diluted? How do we know that public "nudging," 35 if not coercion, ${ }^{36}$ toward less discriminatory religious practices does not affect the religious neutrality determination?

One might argue that, in a particular case, the indirect public funding of religious schools is somehow precisely offset by the increased state influence on the nondiscrimination policies not only of religious schools in general, but also of every religious denomination's schools in particular. These circumstances might establish the public funding's overall neutrality, at least at a particular point in time. ${ }^{37}$ But such a declaration of neutrality-through-offsetting-effects would raise unresolvable problems in

33. 536 U.S. 639, 652 (2002) (summarizing several prior cases).

34. Consider the state tax deduction case of Mueller v. Allen, 463 U.S. 388, 401 (1983).

35. See generally Richard H. Thaler \& Cass R. Sunstein, Nudge: Improving Decisions about Health, Wealth, and Happiness (2008).

36. The Supreme Court has yet to develop a satisfactory jurisprudence as to what counts as coercion in the Religion Clause-or any other-context. See Wright, supra note 21 , at $224-25$.

37. Religious schools might benefit almost immediately from the infusion of cash and students while their nondiscrimination policies might in some respects be nudged by voucher conditions only over time. 
what is called the incommensurability of values. ${ }^{38}$ This would, in reality, amount to a largely meaningless neutrality claim, supported only by arbitrary intuitions. ${ }^{39}$ We might as well describe this rare kind of case as involving two separate forms of supposed non-neutrality-formal and substantive-rather than miraculously offsetting pro- and anti-sectarian effects.

This still concedes too much to the coherence of the idea of neutrality in school funding and related cases. Some may reasonably question whether the pattern of "genuine and independent private choice" 40 by individual parents sufficiently insulates the state from responsibility for the effects of the funding program. The importantly "benefitted" religious denominations will be predictable. Why not, given the predictable, non-neutral pattern of benefits, apply here the legal principle that the government cannot do indirectly what it cannot do directly? ${ }^{41}$

Even if we dismiss all such concerns, we may still sensibly question whether parents' use of school vouchers or tax deductions should be counted as "genuine and independent private choice" 42 in the first place. Whether parents are receiving vouchers, tax deductions, or neither, their choices among sectarian, private secular, or public schools will often reflect a network of costs, benefits, and tradeoffs structured by the government, which the government could at any point modify. Whatever its policies, a government inevitably creates some options and makes other options impractical for some parents. Neutrality, in all relevant and important respects and for all substantially and directly affected parties, is again simply inconceivable. ${ }^{43}$

We need not object to the idea that one aspect of a government program-say, a crèche in a public display-may promote one religion at the expense of other religions and irreligion, while some other aspect of the program or its context is more secular in its popular meaning. ${ }^{44}$ Some

38. For an introduction to value-incommensurability debates, see JAMES GRIFFIN, Well-Being: Its Meaning, Measurement, and Moral Importance 75-92 (1986. See also R. George Wright, Does Free Speech Jurisprudence Rest On a Mistake?: Implications of the Commensurability Debate, 23 Loy. L.A. L. REV. 763 (1990).

39. See generally R. George Wright, Arbitariness: Why the Most Important Idea in Administrative Law Can't Be Defined, and What This Means For the Law in General, $44 \mathrm{U}$. Rich. L. Rev. 839, 839-40 (2010).

40. Zelman v. Simmons-Harris, 536 U.S. 639, 652 (2002).

41. See, e.g., South Coast Air Mgmt. Dist. v. FERC, 621 F.3d 1085, 1092 (9th Cir. 2010); United States v. Whitten, 610 F.3d 168, 194 (2d Cir. 2010) (quoting United States v. Oliveras, 905 F.2d 623, 627-28 \& 628 n.7 (2d Cir. 1990) (per curiam)); Christian Legal Soc'y v. Walker, 453 F.3d 853, 864 (7th Cir. 2006).

42. See Zelman, 536 U.S. at 652 .

43. The classic discussion is presented in Robert L. Hale, Coercion and Distribution in a Supposedly Non-Coercive State, 38 PoL. Scı. Q. 470 (1923). For our purposes, we need not claim that governments ever coerce such parental choices. We need only argue that governments inevitably affect those parental choices in the aggregate, whether intentionally or inadvertently, in ways inconsistent with the most relevant senses of government neutrality.

44. For perhaps the leading Supreme Court case on physical and cultural contextual dilution in the Establishment Clause context, see Lynch v. Donnelly, 465 U.S. 668, 680-81, 689 (1984), County of Allegheny v. ACLU, 492 U.S. 573, 599-602 (1989), and McCreary 
aspects of the surrounding context may "dilute" the religious display in question. ${ }^{45}$ How we know whether the "dilution" is sufficient, but leaves everything neutral, is left to the unavoidably conflicting intuitions of judges. ${ }^{46}$ Also left to judicial intuition would be the permissible forms and the outer boundaries of what should be counted as the various diluting contexts.

Here, we simply assume that all secular objects "dilute," rather than "set off" or highlight a religious object, just as a setting might enhance a gemstone. But even with this doubtful assumption, the overall scenario still cannot meaningfully be described as neutral for Religion Clause purposes. The dilution of a crèche by commercial symbols does not amount to the mutual annihilation of the Christian symbol and the commercial symbols. Both the Christian symbol and the commercial symbols remain present, having their joint and several effects. Either set of symbols might not just dilute, but partially undermine, or even reinforce, the message of the other.

That overall effect, however, of Christian and commercial symbols is not neutral toward all non-Christian religions, or even toward a noncommercial secularism. Is the conjunction of a Christian symbol and commercial consumption symbols neutral toward all forms of Hinduism or Buddhism?47 In what sense do the commercial symbols bring Christianity and Hinduism into neutrality? Why isn't the Christian and commercial display potentially worse from some ascetic Hindu perspectives? In fact, could one not sensibly ask whether the commercial symbols have a non-neutral effect on those forms of Christianity that welcome, and those that reject, familiar forms of commercialism? ? $^{4}$

To go further, why couldn't the neutrality of a government statute or regulation also depend on whether that rule increases or reduces the overall cultural dominance, or the subordination, of religion? Reducing

County v. $A C L U, 545$ U.S. 844, 875-81 (2005). In nondisplay contexts, see, for example, Freedom From Religion Foundation v. Hanover School District, 626 F.3d 1, 12 (1st Cir. 2010).

45. See cases cited supra note 44; Books v. Elkhart Cnty., 401 F.3d 857, 868-69 (7th Cir. 2005); Doe v. Beaumont Indep. Sch. Dist., 240 F.3d 462, 464 (5th Cir. 2001) (en banc) (seeking neutrality not in the challenged program, but in a broader "mosaic" of programs, the outer bounds of the permissible "mosaic" being unspecified).

46. For a discussion, see R. George Wright, The Role of Intuition in Judicial Decisionmaking, 42 Hous. L. REv. 1381 (2006).

47. This assumes that at least some mainstream forms of Hinduism or Buddhism counsel against commercialized purchase of, and attachment to, unnecessary material goods. See, e.g., Damien Keown, Buddhist Ethics 12-13 (2005) (on the broader virtue of nonattachment); THE BHAGAVAD-GitA 36, 39 (Barbara Stoler Miller trans., 1986) (Krishna's Second Teaching on the broader virtue of non-attachment); THE UPANISHADS 33, 55, 64 (Swami Prabhavananda \& Frederick Manchester eds. \& trans., Signet ed. 2002) (1948) (on the virtues of austerity, self-denial, and non-attachment).

48. Compare Max Weber, The Protestant Ethic and the Spirit of Capitalism (Talcott Parsons trans., Charles Scibner's Sons 1958) (1905), with Wisconsin v. Yoder, 406 U.S. 205, 209-12 (1972) (depicting the Old Order Amish ethos), and ST. JoHn ChrysosTOM, ON Wealth ANd POVERTY 40-47 (Catharine P. Roth trans., St. Vladimir's Seminary Press 1999) (c. 389 C.E.) (second sermon), and The Desert Fathers 159 (Helen Waddell trans., 1998). 
the overall dominance of religion or nonreligion could be viewed by some judges as a step toward genuine neutrality. To allow this kind of inquiry, however, would of course be to sink into a quagmire of controversy.

Parallel objections to the idea of neutrality could be raised in any Religion Clause context, and none amount to a demand for absolute perfection or precision in an area in which only a limited degree of precision can reasonably be sought. ${ }^{49}$ The problem is not that the courts have some coherent, workable, and reasonably persuasive sense of religious neutrality that cannot always be easily applied or precisely articulated. ${ }^{50}$ Rather, the problem is that the courts will always have several important neutrality considerations that pull in various, irreconcilable directions.

The courts that apply Religion Clause neutrality often recognize the idea of neutrality as incoherent. Some courts, for example, have been willing to say that Religion Clause neutrality scrupulously adhered to can be biased against, or hostile to, religion. ${ }^{51}$ In so many words, neutrality in the purest sense may not only be non-neutral, but also consistently biased against religion. ${ }^{52}$ Thus, one court announced that "we do not apply an absolute rule of neutrality because doing so would evince a hostility toward religion that the Establishment Clause forbids." 53

Pursuing the paradoxical idea of non-neutral neutrality, we find the Eleventh Circuit particularly unclear on what constitutes a "sectarian" prayer. ${ }^{54}$ The court concluded that a sectarian prayer is constitutional under the Establishment Clause as long as it is not used to proselytize, advance, or disparage a faith..$^{55}$

If we then wonder how an admittedly sectarian prayer could avoid proselytizing or advancing the religion in question, the Eleventh Circuit suggests that context-specifically, legislative prayers versus public

49. Cf. Aristotle, Nicomachean Ethics bk. I, $\S 3$ (W.D. Ross trans., Oxford Univ. Press rev. ed. 2009) (c. 350 B.C.E.) ("Our discussion will be adequate if it has as much clearness as the subject-matter admits of, for precision is not to be sought for alike in all discussions.").

50. See McCreary Cnty. v. ACLU, 545 U.S. 876, 884 (2005); Trunk v. City of San Diego, 629 F.3d 1099, 1106 (9th Cir. 2011) (determinations of unconstitutionality not a matter of detecting "the slightest deviation" from neutrality).

51. See, e.g., Trunk, 629 F.3d at 1105.

52. See id.

53. Id. (quoting Sch. Dist. of Abington Twp., Pa. v. Schempp, 374 U.S. 203, 306 (1963) (Goldberg, J., concurring) ("'[U]ntutored devotion to ... neutrality' can lead to 'a brooding and pervasive devotion to the secular and a passive, or even active, hostility to the religious." ")).

54. See Pelphrey v. Cobb Cnty., 547 F.3d 1263, 1272 (11th Cir. 2008). On a related definitional issue, the Fifth Circuit has distinguished between proselytization and advancement of a religion. See Doe v. Tangipahoa Parish Sch. Bd., 473 F.3d 188, 204 (5th Cir. 2006) ("While 'proselytize' 'necessarily means to seek to "convert" others to that belief', "'advance" means simply to "forward, further, [or] promote" the belief.") (quoting Wynne v. Town of Great Falls, 376 F.3d 292, 300 (4th Cir. 2004)).

55. See Pelphrey, 547 F.3d at 1266 . For some relevant, if not entirely clear definitions, see Wynne, 376 F.3d at 300. One can clearly "advance" or argue on behalf of a proposition without making the slightest progress in actually persuading anyone. 
school commencement prayers-may make a crucial difference ${ }^{56}$ One might equally argue, of course, that a sectarian prayer before mature adults could still proselytize or advance one religion or disparage other religions or irreligion, or that a sectarian prayer at a high school commencement is unlikely to genuinely advance that religion. ${ }^{57}$ On this kind of question, the courts do not seem especially interested in empirical evidence of advancement, assuming such evidence might ever be relevant.

Critics of the Religion Clause neutrality doctrine thus find themselves making what should be the obvious point that what are widely thought to be neutral, nonsectarian, or inclusive prayers are, on common sense standards, plainly not. Why courts have not sufficiently responded to this critique is anyone's guess. This Article seeks to explain this apparent judicial indifference in Part IV below.

As a final example of this apparent indifference, consider many public prayers that are seemingly inclusive or non-sectarian but are clearly not for the simplest of reasons. Often enough, such supposedly neutral prayers are, at a minimum, overtly monotheistic. ${ }^{58}$ Monotheism has of course been historically dominant throughout the United States, but monotheism is obviously not neutral as to polytheism, atheism, or agnosticism. Similarly, such supposedly neutral prayers often are patriarchal in their reference. ${ }^{59}$ This is again culturally unsurprising. But distinctly patriarchal references, even if metaphorically intended, are no more neutral than monotheism. ${ }^{60}$

More importantly, government officials and courts assume that the closer a prayer approaches, in their own eyes, to blandness, abstraction,

56. See Pelphrey, 547 F.3d at 1274 (citing Stein v. Plainwell Cmty. Sch., 822 F.2d 1406, 1409 (6th Cir. 1987)).

57. Consider the possible religious conversions, coerced or otherwise, or the possible lack of any recognizable progress along those lines, from even a sectarian prayer delivered in the circumstances of, for instance, Lee v. Weisman, 505 U.S. 577, 581 (1992).

58. See, e.g., Mellen v. Bunting, 327 F.3d 355, 374 n.12 (4th Cir. 2003) (judicially recognizing the distinctly monotheistic character of the VMI "supper prayer" in question); see also Newdow v. Rio Linda Union Sch. Dist., 597 F.3d 1007, 1101 n.89 (Reinhardt, J., dissenting) (9th Cir. 2010) (describing the Pledge of Allegiance as not neutral towards monotheism and polytheism).

59. See, e.g., Mellen, 327 F.3d at 374 n.12.

60. It is certainly possible to judicially admit the non-neutrality of monotheistic and patriarchal public prayer references while backing away from or diluting any commitment to neutrality. See Croft v. Perry, 624 F.3d 157, 166 (5th Cir. 2010). The court began with an implausible claim to neutrality, but then immediately lowered the bar as to any neutrality requirement, arguing that:

The term God is adequately generic to acknowledge a wide range of religious belief, monotheistic and polytheistic alike. A reference to "God" may not reach every belief system, but it is a "tolerable attempt" at acknowledging religion without favoring a particular sect or belief.

Id. at 166. In English, "God" has a convenient and distinct plural. Socrates may indeed slide between apparent polytheism and monotheism with a certain casualness. See Plato, The Apology, in Euthyphro, Apology, Crito 21, 33 (F.J. Church trans., rev. ed. 1987). But most Americans, fearing accusations of heresy, do not. Nor does even an umbrellalike conception of God encompass most (or all) atheists. Unsurprisingly, the court in Croft adopts the distinct fallback position of pronouncing this degree of neutrality to be good enough for Establishment Clause purposes. Croft, 624 F.3d at 166. 
vagueness, innocuousness (if not utter vacuousness), or Lockean liberal benevolence, the more reasonable it is to characterize the prayer as constitutionally inoffensive, inclusive, and neutral. ${ }^{61}$

This is a mistake. Even among monotheistic religions, these higherorder values are not universally aspired to. Few, if any, monotheistic religions frame their doctrine or prayer in bland, ecumenical, vague, or innocuous language. And blandness, like beauty, is in the eye of the beholder. Intended inoffensiveness may actually be offensive. Clarity, fervency, orthodoxy, militancy, ardor, and differentiation may count for more. ${ }^{62}$ Some deities might prefer being specifically mentioned, others not.

One problem is that most of us, including most judges, as broad Lockean liberals tend to assume that divisiveness is generally a bad thing. ${ }^{63}$ The truth of this normative belief may seem clear, uncontroversial, and thus neutral, but it is not. Emphasizing non-divisiveness is itself divisive. This remains true even if we set aside the further problem that any side to any dispute, given what it takes to be the proper baseline or the proper framing of the issue, can readily accuse the opposing side of being divisive. ${ }^{64}$

The courts, in sum, have not been able to develop an understanding of neutrality in the Religion Clause context that is coherent, workable, or reasonably persuasive. The next part briefly shows that legal scholars and philosophers of the Religion Clauses have not offered much assistance, either in developing such a concept of neutrality or in accounting for the remarkable persistence of implausible claims to Religion Clause neutrality.

\section{THE SCHOLARS ON THE IDEA OF NEUTRALITY}

\section{A. The Religion Clause Context in Particular}

Among scholars, as among the courts, ${ }^{65}$ the question of whether neutrality is an appropriate goal in Religion Clause jurisprudence is often

61. See, for example, the intentions underlying the invocation selection practices in Weisman, 505 U.S. at 581.

62. Consider, for example, James Carroll, Constantine's Sword (2001), and Amin Maalouf, The Crusades Through Arab Eyes (Jan Rothchild trans., Al Saqi Books 1984) (1983). For a smaller-scale religious group not aspiring to be broadly ecumenical, vague, vacuously bland, or in all likelihood much impressed by public prayers of that sort, see the social theology expounded in Snyder v. Phelps, 131 S. Ct. 1207, 1212-13 (2011), and Thomas F. Madden, The New Concise History of the Crusades (rev. ed. 2005).

63. But note that unity, or nondivisiveness, could presumably be achieved under a totalitarian regime based on an objective error.

64. Typically enough, one side is accused of divisiveness in seeking to destabilize a long-established cultural or legal tradition while the opposing side is accused of divisiveness in crucially marginalizing some otherwise clearly established members of the community. Any group that believes itself to hold either a current or future majority might accuse its opponents of divisiveness on some similar basis. Rarely, of course, does a group think of itself as fundamentally divisive.

65. See, e.g., sources cited supra notes 55-57 and accompanying text. 
raised. Jocelyn McClure and Charles Taylor argue that "[i]n a society that is both egalitarian and diverse, the state must be separate from the churches, and the political power must be neutral toward religions." 66 In contrast, Professor Michael McConnell argues that while a focus on neutrality will often suffice to protect the underlying value of religious liberty, ${ }^{67}$ in some contexts "departures from religious neutrality are either permissible or constitutionally required."68

Despite their differences over the value of neutrality, McClure, Taylor, and McConnell assume that in a typical Religion Clause context, the idea of neutrality will at least be meaningful and coherent. In this assumption, these scholars find much support among their peers. Professor Dan Kahan, for example, argues that "[t]he idea that neutrality is incoherent ... is as extravagant as the claim that science, and agreement about it, are impossible in a liberal society." 69 Professor Andrew Koppelman, as well, argues that a fluid, multi-dimensional, high level of abstraction in Religion Clause neutrality is coherent and attractive. ${ }^{70}$

On the other hand, however, some scholars remain skeptical. Professor Steven D. Smith, for instance, argues "that the ideal of religious neutrality is simply not coherent. And if the ideal of neutrality is not coherent, then it makes no sense to urge government to be 'as neutral as possible.' .. . [U]pon reflection, the aspiration is scarcely intelligible."71 At least in the Establishment Clause context, Professor Frank Ravitch argues that apart from some baseline-dependent framework, "neutrality,

66. Jocelyn Maclure \& Charles Taylor, Secularism and Freedom of ConSCIENCE 9-10, 16, 20-21 (Jane Marie Todd trans., 2011) ("The democratic state must therefore be neutral or impartial in its relations with the different faiths.").

67. See Michael W. McConnell, Neutrality Under the Religion Clauses, 81 Nw. U. L. REV. 146, 146-50 (1986).

68. Id. at 149. Professor McConnell believes that there are particular contexts and circumstances in which no genuinely neutral governmental approach to religion may be available. See id. at 151, 164; Gedicks, supra note 3, at 473, 485 ("Religious neutrality presupposes that the purpose of the Free Exercise Clause is to prevent religious discrimination, rather than to protect freedom of action in a domain of religious liberty.").

69. Dan M. Kahan, Foreword: Neutral Principles, Motivated Cognition, and Some Problems for Constitutional Law, 125 HARv. L. REv. 1, 75 (2011) (extending the argument beyond the Religion Clause context).

70. See, e.g., Andrew Koppelman, The Fluidity of Neutrality, 66 REv. PoL. 633 (2004); see also Introduction to First AMENDMENT Stories 4 (Richard W. Garnett \& Andrew Koppelman eds., 2012) (providing a six-part taxonomy of arguments in favor of governmental neutrality toward religion, listing possible arguments from moral pluralism, from futility, from government incompetence, from civil peace, from character, and from dignity) ("[N]eutrality is not a fixed point, but a multidimensional space of possible positions.").

Elsewhere, Professor Garnett suggests that Professor Koppelman's neutrality requirement actually does not require thoroughgoing neutrality. See Richard W. Garnett, Neutrality and the Good of Religious Freedom: An Appreciative Response to Professor Koppelman, 39 PePp. L. Rev. 1001, 1007 (2012). Official silence about questions of religious truth can permissibly be accompanied by governmental messages that both religion itself and religious freedom are valuable. See id.

71. Steven D. Smith, Foreordained Failure: The Quest for a Constitutional Principle of Religious Freedom 94 (1999). See generally id. at 77-95. 
whether formal or substantive, does not exist."72 David Cinotti argues that the term neutrality in the Religion Clause context is "incoherent,"73 in the sense of being "either as vague or ambiguous as to give us no real help, or . . internally contradictory." 74

Courts should thus be aware of problems in neutrality-based Religion Clause case law, primarily from their own experiences, but also from academic dissent, ${ }^{75}$ which views neutrality-based Religion Clause jurisprudence as coherent, workable, and reasonably persuasive. ${ }^{76}$ As we might expect, the scholars have addressed the idea of neutrality in the Religion Clause context, and in the law more generally, distinguishing different meanings of neutrality. The problem, however, is that such distinctions have still not resulted in the coherent use of the idea of neutrality by the courts.

Perhaps the most frequent distinction is that between "formal" neutrality and "substantive" neutrality. Consider the distinction drawn by the well-respected Professor Douglas Laycock; he states that "[f]ormal neutrality requires neutral categories. A law is formally neutral if it does not use religion as a category-if religious and secular examples of the same phenomenon are treated exactly the same." 77 But a law "is substantively neutral if it neither 'encourages [n]or discourages religious belief or disbelief, practice or nonpractice, observance or nonobservance."'78

This distinction may seem intuitive, but like all widely discussed typologies in this area, it quickly frays and unravels. Under Professor Laycock's version of "formal neutrality," scrupulous equality of treatment need not involve treatment that is "exactly the same."79 While separate is not equal, ${ }^{80}$ we can easily imagine, say, two athletes being awarded com-

72. Frank S. Ravitch, A Funny Thing Happened On the Way to Neutrality: Broad Principles, Formalism, and the Establishment Clause, 38 GA. L. REv. 489, 492 (2004).

73. David N. Cinotti, The Incoherence of Neutrality: A Case for Eliminating Neutrality from Religion Clause Jurisprudence, 45 J. CHURCH \& ST. 499, 499 (2003); see also id. at 502 (further elaborating on "absence of government preference" conceptions of Religion Clause neutrality, as well as on conceptions of neutrality focusing on "nonhostility and nonpromotion," "separation," "equal treatment," "equal impact," and on economic-based approaches to neutrality).

74. Id. at 499; see also Miroslav Volf, Public Faith 29 (2011) ("Attempts to reduce what's important in different religions to the same common core are bound to be experienced as disrespecting each religion in its particularity."). For a more sociological perspective, see Stephen Prothero, God Is Not One: The Eight Rival Religions That Run THE World 333-35 (2010). For background, see Huston SMITH, THE World's ReliGIONS (50th anniversary ed. 2009). For a focus on the contemporary American context, see the valuable work of Robert D. Putnam \& David E. Campbell, American Grace: How Religion Divides and Unites Us 493-95, 516-17 (2010).

75. See supra notes 71-74 and accompanying text.

76. See supra notes 66-70 and accompanying text.

77. Douglas Laycock, Substantive Neutrality Revisited, 110 W. VA. L. REv. 51, 54 (2007)

78. Id. at 54-55. Note that the ideas of incentives, and even of encouraging or discouraging, may or may not refer to the intentions of the policymaker. Professor Laycock also distinguishes what he refers to as "disaggregated neutrality." Id. at 54.

79. Id.

80. See Brown v. Bd. of Educ., 347 U.S. 483, 495 (1954) (overruling Plessy v. Ferguson, 163 U.S. 537 (1896)). 
pletely different trophies that are, overall, relatively equal in terms of achievement. Equality or (formal) neutrality need not imply sameness. ${ }^{81}$

Perhaps more importantly, it destabilizes any formal category to define that category in terms of "treatment" 82 of any sort. Treatment in this context is unavoidably vague. Treatment in a formalistic context may refer to something like a theoretical classification in and of itself, as when we debate whether Pluto should count as a planet. But inevitably, the idea of treatment slides from formal into more substantive uses. Someone who complains about abusive treatment, for example, normally does not wish to refer only to some formal classification. Being formally assigned to a particular section of a bus, as under racial segregation, does not exhaust the objectionable treatment.

Put differently, we can judge like things to be alike without treating them the same way. We might, for example, judge two different charities to be alike and yet contribute our only dollar bill to one of the charities based on grounds other than the merits of the charities, thus treating the charities differently. ${ }^{83}$

Similarly, Professor Laycock's conception of substantive neutrality ${ }^{84}$ is unstable in its simultaneous over-ambitiousness and under-inclusiveness. For reasons akin to those presented above in connection with the neutrality case law itself, ${ }^{85}$ Professor Laycock's substantive neutrality is not only unattainable, but also unapproachable. No rule that significantly affects one or more religions, or any irreligion, can be said to be simply neutral across the board, since its effects are somehow properly weighed over some selected time frame. ${ }^{86}$ The important impacts of any such rule on different groups will inevitably vary.

Professor Laycock's substantive neutrality actually does not focus on the effects of a policy; rather, it focuses on the incentives created by the policy in question. ${ }^{87}$ Incentives are not effects. There is still a major problem of over-ambition in requiring the universal neutrality of a policy's intended and unintended incentives. But the distinct problem here is that however we define incentives, they are not the same as the policy's effects. We often care more about a policy's actual effects-whether or not intended or foreseeable-than about the perverse or ineffective incentives created by a policy. ${ }^{88}$ Incentives may fail. The relevant actors

81. See, e.g., Albert W. Alschuler, The Failure of Sentencing Guidelines: A Plea for Less Aggregation, 58 U. CHI. L. Rev. 901, 916 (1991); Reva B. Siegel, Constitutional Culture, Social Movement Conflict and Constitutional Change: The Case of the De Facto ERA, 94 CALIf. L. Rev. 1323, 1382 n.158 (2006) ("'Equality' does not mean 'sameness." ").

82. See supra note 77 and accompanying text.

83. See Norman C. Gillespie, On Treating Like Cases Differently, 25 PHIL. Q. 151, 151 (1975).

84. See supra note 78 and accompanying text.

85. See supra Part II.

86. See id.

87. See supra text accompanying note 78 .

88. Consider the unforeseen consequences of individual decisions in a market as described in Adam Smith, The Wealth of Nations 351 (Prometheus abr. ed. 1991) (1776). See also Bernard de Mandeville, The Fable of the Bees: Or, Private Vices, Pub- 
may not respond to a policy's incentives. Incentives may backfire. The actual effects of a policy may be crucial in practice. ${ }^{89}$

In any event, Professor Laycock's approach to neutrality in the Religion Clause context, like any mainstream approach, is unstable and selfdestructing. It is unintentionally unattainable and unduly indeterminate. His approach seems to do too much, too little, the wrong thing, or inconsistent things. My point instead goes to the nonviability of Religion Clause neutrality in general under any mainstream formulation..$^{90}$

\section{B. Is the Legal Scholarship on Neutrality Beyond the Religion Clause Context of Any Assistance?}

Famously, Professor Herbert Wechsler sought to limit judicial arbitrariness; politicized judging; and immediate, result-oriented case adjudication by emphasizing the proper role of "neutral principles." 91 Professor Wechsler sought a judicial decision "that rests on reasons with respect to all the issues in the case, reasons that in their generality and their neutrality transcend any immediate result that is involved." 92

The problem with this approach to neutrality is that it easily accommodates the most thoroughly partisan and ideologically driven judges for whom the Constitution is an instrument-or perhaps an obstacle. Such partisan judges can certainly offer Wechslerian reasons for their decisions on all of the issues in the case. Thus, there are, as John Hart Ely observed, "neutral principles of every hue." 93 And such judges, probably more than most others, will be seeking through their judicial reasoning to "transcend any immediate result" 94 in the case. Presumably, the highly partisan judge's aim would be to advance broadly and over time a preexisting political agenda, which could be formulated in terms of reasons and principles at various levels of generality.

LICK BENEFITS (Penguin 2010) (1714). For a more specific focus on important unforeseen or unintended consequences, see, for example, Frederic Bastiat, THat Which is Seen, and That Which is Not Seen (1850), available at http://bastiat.org/en/twisatwins.html (last visited Mar. 9, 2012); Robert K. Merton, The Unanticipated Consequences of Purposive Action, 1 АM. Soc. REv. 894, 894-95 (1936).

89. See sources cited supra note 88.

90. See, e.g., Rafael Palomino, Religion and Neutrality: Myth, Principle, and Meaning, 2011 BYU L. REv. 657, 678 (distinguishing between "strict neutrality" or "the neutrality of indifference," "nondiscriminatory neutrality," and "benevolent neutrality," on the one hand and "indifference," presumably being distinct from benevolence, on the other hand); John T. Valauri, The Concept of Neutrality in Establishment Clause Doctrine, 48 U. PrTT. L. REv. 83, 108 (1986) (distinguishing between principles that are "neutral in their application" and principles that are also "neutral in their derivation").

91. Herbert Wechsler, Toward Neutral Principles of Constitutional Law, 73 HARv. L. Rev. 1, 11-20 (1959). See generally Barry Friedman, Neutral Principles: A Retrospective, 50 VAND. L. REV. 503, 504-07 (1997).

92. Wechsler, supra note 91 , at 19.

93. John Hart Ely, Democracy and Distrust: A Theory of Judicial Review 55 (1980), quoted in Pamela Karlan, What Can Brown $®$ Do For You?: Neutral Principles and the Struggle Over the Equal Protection Clause, 58 Duke L.J. 1049, 1058 (2009).

94. Wechsler, supra note 91, at 19. 
A partisan judge could, for instance, be driven by the overriding general principle: "Always promote the interests of your own economic class." 95 Such a principle is general and not exhausted by the result in any given case. It is in that Wechslerian sense a neutral principle. But for detractors, it is unlikely to qualify as neutral in the most meaningful and important senses. Consistency, as Professor Mark Tushnet classically observed, does not effectively constrain judges to neutrality in the desired senses. ${ }^{96}$

For a time, some scholars thought that the ideal of liberal democratic government could be expressed in terms of the government's neutrality toward the citizenry's various legitimate conceptions of a good life. ${ }^{97}$ Specifically, this view held that government should be neutral, or as a neutral as possible, toward various understandings of the good. This neutralist view could be critiqued as unattractive-perhaps a legitimate liberal state can and should encourage certain conceptions of the good life as distinct from others. ${ }^{98}$ But the more basic critique of broad liberal neutrality, rather like Religion Clause neutrality, is that it is unapproachable, if not entirely incoherent.

Much of the latter problem stems from the fact that liberal neutrality appears to embody a clear and simple idea-but it actually does not. The most careful typology of liberal neutrality generates several distinct dimensions of neutrality and non-neutrality. ${ }^{99}$ The internal tradeoffs

95. Some such formulation might be thought by an interpreter of Marx to suggest a normative Marxism. See The Marx-Engels Reader 161 (Robert C. Tucker ed., 2d. ed. 1978).

96. See Gerald E. Frug, Why Neutrality?, 92 Yale L.J. 1591, 1591-92 (1983); Mark V. Tushnet, Following the Rules Laid Down: A Critique of Interpretivism and Neutral Principles, 96 Harv. L. Rev. 781, 805 (1983).

97. See, e.g., Bruce A. Ackerman, Social Justice in the Liberal State 10-12 (1980); Ronald Dworkin, A Matter of Principle 181-201 (1985); Charles E. Larmore, Patterns of Moral Complexity 50-55 (1987); Will Kymlicka, Liberal Individualism and Liberal Neutrality, 99 ETHICs 883, 883 (1989) (stating the basic liberal neutrality thesis).

98. See generally George Sher, Beyond Neutrality: Perfectionism and Politics (1997); Joseph Raz, The Morality of Freedom (1986).

99. For a sense of the inescapable, bewildering complexity, see, for example, the elaborate and distinct typologies of neutrality presented in Gerald F. Gaus, Liberal Neutrality: A Compelling and Radical Principle, http:/gaus.biz/GausOnNeutrality.pdf (last visited Dec. 7, 2011) ("[I]nterpretations of neutrality are far more diverse than most analyses recognize.") (recognizing over a dozen such distinctions); Peter de Marneffe, The Slipperiness of Neutrality, 32 Soc. Theory \& Prac. 17, 19 (2006) (distinguishing, "among others," eleven distinct kinds of non-neutral reasons leading to the suspicion that "there is in fact no satisfactory theoretical account of the intuitive distinction between neutral and nonneutral reasons"). For a recent defense of a version of liberal neutrality that itself refers to numerous possible forms thereof, see Alan Patten, Liberal Neutrality: A Reinterpretation and Defense, 20 J. PoL. PHIL. 249, 249-52 (2012). For a much simpler but helpful typology of liberal neutrality, see, for example, Richard Arneson, Liberal Neutrality on the Good: An Autopsy, in Perfectionism and Neutrality: Essays in Liberal Theory 191 (George Klosko \& Steven Wall eds., 2003), available at http://philosophyfaculty.ucsd.edu/ faculty/rarneson/neutrality.pdf (last visited Mar. 12, 2012) (distinguishing between "neutrality of aim," "neutrality of effect," and "neutrality of justification"); Kymlicka, supra note 97, at 883-84 (distinguishing between "neutrality in the consequences of government policy" and "neutrality in the justification of government policy"). 
among types of neutrality would remain even if we could settle on the meaning and measure of each possible element of liberal neutrality.

This Article will not address the merits of liberal neutrality. Nor will it compare liberal neutrality to any form of neutrality in the Religion Clause context. But it should come as no surprise that in both contexts, "[g]overnments play quite a significant role in shaping both the form and context of [societal or religious group] demands, interests, and preferences." 100 It is difficult to see government policies as neutral when they help shape the very groups and institutions toward which they are claimed to be neutral. Governmental soil, as it were, cannot be equally hospitable to all possible worthwhile plants.

Consider a brief hypothetical on a school voucher case ${ }^{101}$ in which a government program transfers $\$ 10,000$ each to a number of secular organizations, but transfers only $\$ 1,000$ to each of a number of religious organizations. All else being equal, can we even begin to assess whether the government's collective intent is somehow neutral? ${ }^{102}$ Can we even begin to determine the relevant effects of this policy? ${ }^{103}$ A small sum to group A may be far more meaningful than a larger sum to group B. Note that some, if not all, legislators enacting the above policy might expect and hope that for the religious groups receiving the smaller amount, such a sum would dramatically change their ways of life, whereas no such change is expected or wished for those groups receiving the far larger amount.

Evidently, expanding our focus to matters such as general neutrality principles, ${ }^{104}$ or liberal neutrality, ${ }^{105}$ does not significantly help with the inconsistencies within Religion Clause neutrality. ${ }^{106}$

\section{WHAT COULD RELIGION CLAUSE NEUTRALITY POSSIBLY AMOUNT TO?}

In the typical formulations from both the case law ${ }^{107}$ and the leading scholarship, ${ }^{108}$ the idea of Religion Clause neutrality is not coherent. But rather than simply abandoning the idea of neutrality, perhaps prematurely, this part briefly considers seven related alternative ways of thinking about neutrality in the Religion Clause area.

Perhaps evidently incoherent ideas can still have uses or functions. Perhaps the idea of neutrality can be reconceived. We will briefly con-

100. Patrick Neal, Liberalism \& Neutrality, 17 Polity 664, 671 (1985).

101. See, e.g., Zelman v. Simmons-Harris, 536 U.S. 639, 643-46 (2002).

102. See, e.g., Kwame Anthony Appiah, Neutrality Reconsidered, CENTRE DE RECHERCHE EN ETHIQUE DE L'UNIVERSITÉ DE MONTRÉAL, http://www.creum.umontreal. ca/IMG/doc/appiah.doc (last visited Jan. 23, 2012).

103. See id.

104. See supra notes $91-96$ and accompanying text.

105. See supra notes $97-102$ and accompanying text.

106. See supra Part II.

107. See cases cited supra notes 1-2; supra Part II.

108. See scholarly literature cited supra note 1; supra Part III. 
sider the possible appeal and the defects of these seven alternative approaches or "rescue attempts." In the end, though, none of the seven alternatives, alone or in combination, can successfully rescue of the concept of Religion Clause neutrality. Our aim below in considering possible approaches to rescuing at least some use of neutrality language is to generate a sense of the possible benefits along with the clear limits and costs of such approaches. Ultimately, though, none of these seven alternatives will suffice, and we will be forced to turn to a surprising analogy to a remote area of the law. Neutrality cannot be recovered, but it can be creatively replaced.

\section{A. Unfazed Optimism: Perhaps Something Will Yet Turn Up}

First, many courts continue to believe in the coherence, workability, and persuasive appeal of standard ideas of Religion Clause neutrality. Or at the very least they expect that some version of Religion Clause neutrality will eventually develop and validate the case law. Some scholars share the courts' general optimism in this regard. ${ }^{109}$

Unfortunately, the coherence problems of Religion Clause neutrality, as the case law is normally interpreted, do not seem resolvable, thus we do not seem poised for a neutrality breakthrough. Some other perspective, approach, interpretation, or combination thereof is required if Religion Clause neutrality language is to be recovered. There can certainly be no guarantee that any such rescue attempt will prove satisfactory.

\section{B. The Possible Special Judicial Manipulability of Neutrality}

Second, it might dishearteningly be the case that the standard approaches to Religion Clause neutrality retain their appeal in part because of their general vulnerability to conscious and subconscious manipulation by the courts. The manipulability of the neutrality concept would, whatever its long-term impact on the law, have an appeal, at least subconsciously, for a number of courts. ${ }^{110}$ The incoherence of neutrality, whether recognized or not, would on this view often count as a feature rather than a vice.

The more manipulable the legal doctrine, the less predictable the cases that turn on that doctrine are. And it is hardly foregone that manipulability should prevail over predictability. ${ }^{111}$ Furthermore, whether the standard idea of Religion Clause neutrality is distinctively more manipulable than replacement ideas is unclear. The idea of "coercion," for ex-

109. See, e.g., sources cited supra notes $69-70$ and accompanying text.

110. For a sense of the judicial manipulability of ideas such as "narrowness" or "narrow tailoring," see, for example, R. George Wright, Electoral Lies and the Broader Problems of Strict Scrutiny, 64 FLA. L. Rev. 759, 777-78 (2012); R. George Wright, The Fourteen Faces of Narrowness: How Courts Legitimize What They Do, 31 LoY. L.A. L. Rev. 167, 194-95 (1997).

111. See, e.g., Tom Bingham, The Rule of Law 37-47 (2010). 
ample, looms increasingly large in Establishment Clause cases. ${ }^{112}$ But the idea of coercion in that context has never been expounded on. ${ }^{113}$ It is fair to say that the idea of coercion can be substantially manipulated by judges.

There would also be a need for a good theory why any currently dominant voting bloc on the Supreme Court would prefer manipulability in ideas crucial to their constitutional decisions. A high level of manipulability, after all, would promote the erosion, in substance if not in name, of their own precedents. Perhaps current court majorities expect to see their favorite precedents eroded for other reasons, or else they imagine those precedents to be somehow entrenched and invulnerable to change. The idea of neutrality would be unlikely to meet these expectations.

\section{The Essential Contestability of Neutrality}

A third alternative approach to the incoherence of neutrality in the Religion Clause cases draws on work, familiar to political scientists and philosophers, by Professor W.B. Gallie. ${ }^{114}$ Gallie developed the idea of what he called "essentially contested" 115 concepts. ${ }^{116}$ Think, for example, of the ways "democracy" was used internationally throughout the 20th century. Professor Gallie wrote that some ideas about even the core, central meaning of essentially contested concepts may not be "resolvable by argument of any kind, [but] are nevertheless sustained by perfectly respectable arguments and evidence." 117 This condition indicates that a concept is essentially contestable. ${ }^{118}$

More loosely, reliance upon essentially contestable concepts "inevitably involves endless disputes about their proper uses on the part of their users." 119 In practice, to use an essentially contested concept "means to use it against other uses" and to recognize that "one's own use of it has to be maintained [or defended] against these other uses."120

112. See, e.g., Wright, supra note 21 , at 195 .

113. See id. The multiple manipulability of the related three part Lemon test is similar. See Lemon v. Kurtzman, 403 U.S. 602, 612-13 (1971); Peter Westen, The Empty Idea of Equality, 95 HARV. L. REv. 537, 559-77 (1982) (taking the controversial position that the concept of equality is "entirely superfluous").

114. See generally W.B. Gallie, Essentially Contested Concepts, 56 PROC. OF THE ARISTOTELIAN SOC'Y 167 (1955-1956).

115. See id. at 167.

116. See id. at $169-72$.

117. Id. at 169 .

118. See id.

119. Id.

120. Id. at 172. For further discussion of the idea of essentially contestable concepts, see, for example, William E. Connolly, The Terms of Political Discourse 9-43 (Princeton Univ. Press 3d ed. 1993) (1974); John Gray, On Liberty, Liberalism and Essential Contestability, 8 BRIT. J. Pol. SCI. 385, 388-95 (1978); K.I. MacDonald, Is 'Power' Essentially Contested?, 6 BrIT. J. Pol. Scr. 380 (1976); David-Hillel Ruben, W.B. Gallie and Essentially Contested Concepts, 39 PHIL. PAPERS 259 (2010); Christine Swanton, On the "Essential Contestedness" of Political Concepts, 95 ETHIcs 811, 811 (1985) (expressing doubt as to whether the crucial political concepts should count as essentially contestable); Jeremy Waldron, Is the Rule of Law an Essentially Contested Concept (in Florida?), 21 L. \& 
Can we say that the idea of neutrality in the Religion Clause cases qualifies, whether the courts recognize it or not, as an essentially contestable concept? Doubtless some factors of essential contestability are present to some degree, and this may help account for the persistence of neutrality talk in the case law. But neutrality in our context does not present a classic case of essential contestability.

As an example, consider the idea of "democracy"; some would apply the term democratic to the United States and deny that Cuba counted as a democracy, while others would maintain the opposite. ${ }^{121}$ Different core criteria for democracy are being applied, perhaps unconsciously. But this does not seem paralleled in the debates over religious neutrality. As we saw above, ${ }^{122}$ for example, critics of the neutrality cases often argue that a case incorrectly found a practice to be neutral on the deciding court's own use or understanding of the idea of neutrality. The critic of the court's logic of neutrality need not adopt any personal idea of neutrality, whether the same as the court's idea of neutrality or not. There is no conceptual contest.

Suppose a critic of a court decision says that a public cross, contextually diluted by various secular objects, is not neutral as against a number of the major world religions. ${ }^{123}$ It seems likely that the critic is not simply "talking past" the court or using the term neutral in a substantially different sense with different criteria. The critic and the court are not contesting the conceptual meaning. Rather, the critic may well be saying that on the court's own logic, understanding, or definitions, the secularly diluted cross display is not neutral. The court holding otherwise may thus directly contradict itself based on its own specified criteria for neutrality.

The idea that Religion Clause neutrality is an essentially contestable concept may thus contribute modestly toward our understanding of what would otherwise appear to be sheer incoherences in the case law. But the idea of essential contestability is not fully applicable and cannot bear much of the burden of explaining or rehabilitating Religion Clause neutrality.

PHIL. 137, 148-59 (2002). We can only hope that truth itself is not an essentially contestable concept, lest we wind up with the awkward claim that it is true that the concept of truth is essentially contestable. See generally David Enoch, How Is Moral Disagreement a Problem For Realism?, 13 J. ETHICs 15, 48 (2009).

121. It is possible that those who see either the United States or Cuba as a democracy to the exclusion of the other may accuse each other of self-contradiction. But this sort of argument seems rarer than contesting for one's preferred, distinct meaning of democracy. Perhaps one or both contestants over the preferable meaning of "democracy" are at some level engaged in a self-contradiction. But such a self-contradiction, if any, will be less direct and immediate than that often claimed in the Religion Clause neutrality debates.

122. See, e.g., supra note 47 and accompanying text.

123. See supra note 47 and accompanying text. At this time, we need not endorse or reject any such critique on the merits. 


\section{Neutrality As a Legal Fiction}

A fourth possible approach to the incoherences of Religion Clause neutrality, however, holds more promise. Here, we draw on Professor Lon Fuller's classic discussion of "legal fictions." 124 Could judicial declarations that a given practice counts as neutral under the Religion Clauses-or even as not neutral-be explained as legal fictions?

Fuller held that a legal fiction "is neither a truthful statement, nor a lie, nor an erroneous conclusion." 125 It is not entirely clear, on Fuller's account, whether a claim that is incoherent could also qualify as a legal fiction, or whether a claim that is known by its author to be incoherent could qualify. At one point, Fuller refers to a legal fiction as "an "expedient, but consciously false assumption." "126 This would seem to exclude the typical judges who believe that the doctrine of Religion Clause neutrality is logically sound.

On the other hand, Fuller also broadly refers to a legal fiction as "an expedient but false assumption." 127 This formulation would not require a judge's awareness of falsity or of incoherence. And Fuller also allows for the possibility that the author of a legal fiction "may have believed it in the sense that he could think of no better way of expressing the idea he had in mind." 128 This formulation allows for additional latitude. Perhaps some judges believe, consciously or not, that even if Religion Clause neutrality is incoherent, it is a necessary doctrine and is the best we will get. Neutrality has favorable connotations and strong cultural associations with fairness.

How a judge is to apply an incoherent doctrine "faithfully,"129 or consistently on its own terms, would remain murky. But the judge could instead choose to emphasize the role of legal fictions in pragmatically making the best of what the judge, for good or bad reasons, assumes to be an inevitably bad situation, whether or not other Religion Clause courts recognize their logically awkward position.

The real problem with thinking of Religion Clause neutrality as a legal fiction is that we do not know whether the fiction involved is expedient or pragmatically useful, or whether an incoherent but culturally appealing idea of neutrality is really the best that judges can do under their circumstances. For example, assume that a rural town council in a religiously

124. See generally Lon L. Fuller, Legal Fictions (1967). See also Kenneth Campbell, Fuller On Legal Fictions, 2 L. \& PHIL. 339, 340-41 (1983).

125. FulLER, supra note 124 , at 5.

126. Id. at 7 (quoting Hans Vaihinger, Die Philasophie des Als Ob 130 (4th ed. 1920)).

127. Id. at 9 (emphasis omitted); see also Campbell, supra note 124, at 362 (A fiction "can perfectly well exist before the realisation that it is such.").

128. Fuller, supra note 124 , at 8 . The broader the idea of a legal fiction is defined, the closer the idea approaches the general legal modifier of "constructive," as in the case of, say, a constructive discharge, or a discharge that is, for policy reasons, deemed to have occurred even though no discharge in fact took place. See Nancy J. Knauer, Legal Fictions and Juristic Truth, 23 St. Thomas L. Rev. 1, 1-2 (2010-2011).

129. Peter J. Smith, New Legal Fictions, 95 Geo. L.J. 1435, 1471 (2007). 
homogeneous area ${ }^{130}$ is permitted to use at public meetings a series of what are usually thought of as bland, and therefore inoffensive, monotheistic and literally patriarchal invocations. Why not claim that such a practice, even if not coherently or genuinely neutral, pays for itself by promoting majority community values and local solidarity?

One obvious pragmatic cost is the possibility of thereby validating, and reinforcing, the community's insularity at a time when the costs of cultural parochialism may be increasing. ${ }^{131}$ We will leave this as an unresolved problem for those who view Religion Clause neutrality not only as a legal fiction, but one that is genuinely useful and broadly expedient. We will have a bit more to say about whether we can do any better than a focus on neutrality.

\section{E. Neutrality and the Analogy to Moral Fictionalism}

A fifth approach to explaining, if not rescuing, the apparent incoherence of Religion Clause neutrality draws by analogy on an increasingly influential way of thinking about the meaning of moral language known as "moral fictionalism." 132 Contemporary advocates of moral fictionalism differ among themselves as to how to formulate the general idea. ${ }^{133}$ According to Professor Richard Joyce, virtually all ordinary moral claims are false, ${ }^{134}$ but we continue to use moral language and even moral propositions without believing or even asserting those moral propositions. ${ }^{135}$ This may well sound a bit curious. The idea is roughly that continuing to use moral language the way a recognized story teller ${ }^{136}$ might spin a yarn-as a sort of conscious lie-to-children-will have a useful payoff, 137 or, at the very least, that things would be worse for us if our moral claims were intended to assert moral truths, but our moral assertions were all

130. For the plausibility of such a scenario, see BILL BISHOP, THE BIG SORT: WHY THE Clustering of Like-Minded America Is Tearing Us Apart (2008).

131. Arguably, one of the important themes of PutNam \& CAMPBELl, supra note 74 , at 494 , is that despite increasing religious polarization, personal interactions of various sorts between those of different faiths, rather than implicit exclusions, tend to promote increased inter-group tolerance. This theme would presumably argue against even unintentionally exclusivist public religious ceremonies.

132. For some basic contemporary sources, see Richard Joyce, THE MYTH OF Morality 206-31 (2001), and Mark Eli Kalderon, Moral Fictionalism (2005).

133. See, e.g., Richard Joyce, Review of Kalderon, M.E., Moral Fictionalism, 85 PHIL. \& Phenomenological Res. 161 (2012) (distinguishing between "revolutionary" moral fictionalism based in pragmatism and error theory and Kalderon's "hermeneutical" moral fictionalism, which instead aims to describe what we have been intending to do with moral language all along); KALDERON, supra note 132, at 138-39.

134. See JOYCE, supra note 132, at 185.

135. See id. at xi; KALDERON, supra note 132, at vii, 112.

136. See JoyCE, supra note 132, at xi. Professor Kalderon speaks in terms of moral propositions as conveying "relevant noncognitive attitudes." KaLDERON, supra note 132, at vii. Compare that to the "quasi-realism" of Simon BlackBurn, Essays in Quasi-ReALISM 3 (1993). By analogy, a judge might affirm "all that could ever properly be meant by saying that" a given practice was, for example, constitutionally neutral. Id. at 157.

137. See JOYCE, supra note 132, at 185. 
concluded to be baseless, incoherent, or false. ${ }^{138}$

Could some version of moral fictionalism-a Religion Clause fictionalism-be adopted to help account for the persistence of what otherwise appears to be an incoherent collection of judicial assertions regarding Religion Clause neutrality? It would be quite a stretch to assume that most courts consciously avoid asserting any moral or legal truth when they declare that a particular religious practice is or is not constitutionally neutral. Courts are not just telling us an evocative, make-believe story to help make the world a better place on some judicially unspecified standards.

It is certainly possible that neutrality stories might make the world a better place, perhaps by inspiring us, or simply moving us, to adopt different values and perspectives. But many of us would stubbornly want to know why one judicial outcome is thought to be better than another, and why this explanation itself might not be used to decide Religion Clause cases more directly.

In the meantime, if the courts announced on the basis of good reasons independent of asserted moral or legal truths that they had abandoned the pursuit of moral or legal truths, we might give them credit for insightfulness, or at least candor. But this admission might also undermine the courts' legitimacy and authority, both in the Religion Clause area and more broadly. Would we find useful a court's admission that there are no true moral or legal assertions to be made in areas such as equal protection or substantive due process as well? ${ }^{139}$

Even if a fictionalist approach to Religion Clause neutrality did not gradually undermine judicial legitimacy in Religion Clause cases, it is unclear that such fictionalism would be of much pragmatic use. Courts would still have to choose one outcome or another and tell one recognized make-believe story or another in any given case. Many good stories come into conflict with one another. Conflicting characters can evoke both envy and admiration. It is unclear how much the fictionalist approach to neutrality would be doing. The crucial judicial choices are those concerning what counts as pragmatically useful and which judicial outcomes would best promote the approach's usefulness. The real problem, ultimately, would be to work out a satisfactory approach to, and defense of, judicial pragmatism. ${ }^{140}$

138. For some representative responses, see, for example, Zed Adams, Review of Kalderon, 117 EтнICs 131, 131 (2006); Daniel Demetriou \& Graham Oddie, Review of Kalderon, 116 Mind 439, 439 (2007); Andrew Fisher, Review of Kalderon, 57 PHIL. Q. 145, 147-48 (2007); James Lenman, Against Moral Fictionalism, 49 PHIL. Books 23, 32 (2008); Hugo Meynell, Review of Kalderon, 48 HeYthrop J. 827, 827-28 (2007).

139. Some still find inspiration in Václav Havel's declaration that "I merely take the side of truth against lies, the side of sense against nonsense, the side of justice against injustice." Vaclav Havel, Open Letters: Selected Writings 1965-1990 248 (Paul Wilson ed. \& trans., 1991).

140. For a skeptical view, see R. George Wright, Pragmatism and Freedom of Speech, 80 N.D. L. Rev. 103, 104-05 (2004). For a brief statement of contemporary pragmatism, 


\section{F. Neutrality and the Analogy to Moral "Error Theory"}

As a sixth approach, some forms of moral fictionalism ${ }^{141}$ already incorporate an element of what is called "error theory." 142 By itself, moral error theory holds that the moral judgments that we assert are systematically false or incoherent. Under Professor John Mackie's formulation, "although most people in making moral judgments implicitly claim ... to be pointing to something objectively prescriptive, these claims are all false."143 There is, for example, nothing in the world that corresponds to the supposed objective truth and prescriptive character of our assertions that murder is morally wrong or that the separation of church and state is morally sound or important. ${ }^{144}$

Could an error theory of morality be applied by analogy to the Religion Clause neutrality case law? Again, as with the moral fictionalism analogy, it is plausible that most judges in the Religion Clause cases are not consciously adapting or analogizing to the philosophical discussions of moral error theory. At most, judges could instead be influenced indirectly by some popularized versions of moral error theory.

Consider how a legal or constitutional error theory, by analogy to a moral error theory, might operate. The simplest version, as applied to our Religion Clause cases, would start by assuming some fairly standard idea of what Religion Clause neutrality is supposed to mean. ${ }^{145}$ A judge might then conclude that statements such as "this practice is religiously neutral under the First Amendment" must be false or incoherent, for entirely sensible reasons like those discussed above. ${ }^{146}$

That conclusion could be the core of a "legal error theory" in our particular context. But the judge would then still face a choice as to how to act. One option, at least for the Supreme Court, would be to abandon its Religion Clause neutrality jurisprudence. ${ }^{147}$ Why persist in recognized falsity or incoherence? But as we noted in connection with the judicial analogy to the theory of moral fictionalism, ${ }^{148}$ the courts need not com-

see the contribution of Richard Rorty in RICHARD RORTY \& PASCAL ENGEL, WHAT'S THE UsE OF TruTH? 37, 40-41 (Patrick Savidan ed., William McCuaig trans., 2007).

141. See JoYCE, supra note 132, at 206-31; Richard Joyce, The Error in 'The Error in the Error Theory, 89 Australdasian J. Phil. 519, 519-20 (2011).

142. See J.L. Mackie, Ethics: Inventing Right and Wrong 35, 239 (1977) (discussion of "error theory"); see also, e.g., Michael Smith, Beyond the Error Theory, in A World Without Values: Essays ON John Mackie's Moral Error Theory 119, 119-21 (Richard Joyce \& Simon Kirchin eds., 2010); Chris Daly \& David Liggins, In Defence of Error Theory, 149 PHIL. STUD. 209, 210-21 (2010); Hallvard Lillehammer, Moral Error Theory, 104 Proc. Aristotelian Soc'y 95, 96 (2004); Alexander Miller, Wright's Argument Against Error-Theories, 62 ANALYsIs 98 (2002); Russ Shafer-Landau, Error Theory and the Possibility of Normative Ethics, 15 PhiL. Issues 107, 108-09 (2005).

143. MACKIE, supra note 142 , at 35.

144. See id. at 15 ("[V]alues are not objective, are not part of the fabric of the world," despite our presumed beliefs to the contrary.).

145. See, e.g., supra note 3 and accompanying text; see generally Part II.

146. See supra Parts II, III.A.

147. Courts, bound by Supreme Court precedent, could still in dicta express their skepticism of the neutrality approach's coherence.

148. See supra Part IV.E. 
pletely abandon Religion Clause neutrality language for such reasons.

Instead, a judge adhering to error theory might continue using neutrality language not to convey legal truths, but to achieve some chosen pragmatic goal. Perhaps the idea would be to use false or incoherent neutrality language as part of a rhetorical attempt to reduce (or enhance) cultural conflict on a religious issue, or to increase (or decrease) the emotional appeal of some religious legislation, practice, or display. ${ }^{149}$ People can be motivated by language that does not seek to assert true propositions.

But this version of error theory would inherit the defects of its fictionalist counterpart, as noted above. ${ }^{150}$ The error theory judge would concede that any assertions about, say, the neutrality (or non-neutrality) of a public religious prayer would be false or incoherent. That concession might, over time, limit the pragmatic impact of the judge's accompanying discussion. We would want to know what logical purpose, if any, the reference to neutrality serves. Why not opt for judicial rhetoric with a substantive focus other than on an unconvincing neutrality?

We would doubtless want to know why (i.e., on what grounds) the judge had decided that one judicial outcome was more pragmatically desirable, or otherwise useful, than another. For example, is there a consensus on whether the legislative prayers permitted in Marsh $v$. Chambers ${ }^{151}$ were then pragmatically or otherwise useful or that they would be useful today? Why would we see such prayers as having, or not having, an overall pragmatic payoff? The essence of the judicial opinion would really not involve the question of neutrality or non-neutrality, but the court's grounds for preferring one view of what is useful, 152 and how the case holding would promote the desired consequences. ${ }^{153}$ Would we likely not be back to debates about baselines, divisiveness, inclusion, equality, respect, deserved sympathy, and similar questions?

149. Consider, by further analogy, the weight ascribed to a purely emotive meaning, as distinct from cognitive meaning, in the draft protest jacket case of Cohen v. California, 403 U.S. 15, 26 (1971). See also, e.g., J.O. Urmson, The Emotive Theory of Ethics 11 (1968).

150. See supra notes $139-40$ and accompanying text.

151. 463 U.S. 783, 793 (1983).

152. Is it, for example, useful to try to solemnize a public occasion with some sort of conventional prayer? This question is not rhetorical and may raise all the familiar Establishment Clause and Free Exercise Clause questions.

153. Having abandoned any claim that a practice can objectively be religiously neutral under the First Amendment, the courts might wish to maintain the authority and legitimacy of judicial review in Religion Clause cases by articulating some theory of how, in a given case, the rhetoric without the substance of neutrality might contribute to desired public consequences. People can, for example, be motivated, in large numbers and over time, even by what they recognize to be nonexistent entities. See, e.g., McGrufF.org, http://www.mcgruff.org/\#/main (last visited July 8, 2012) ("tak[ing] a bite out of crime"); SMOKeyBear.com, http://www.smokeybear.com (last visited July 8, 2012) (helping prevent wildfires); Woodsy-Owl, U.S. DEP'T of AGRIc., http://www.fs.usda.gov/main/conservationeducation/smokey-woods/woodsy-owl (last visited July 8,2012 ) (lending a hand to care for the land). 


\section{G. Shrinking the Universe of Relevant Test Cases: Could COURTS Just Lower THE BAR FOR Religious Neutrality?}

Our seventh and final alternative approach to neutrality in the Religion Clause cases also draws on a loose analogy to a current philosophy. Consider a background example. Suppose that someone is asked whether she knows that a pencil is on her desk. Without much reflection, she says yes. For most purposes, we typically have no objection to her saying so.

But notice what has happened here. A person claims that she knows there is a pencil on her desk. At least subconsciously, though, she has only taken some of the (arguably) relevant factors into account and has ignored others. She may, for example, have considered her proximity to the desk, her certainty that the desk is hers, the lighting conditions, her unobstructed view, and her visual acuity, among other factors. But she also will have ignored other relevant, albeit unusual, considerations. These ignored considerations might include the possibility that what appears to be a pencil is really not, or that she has been hypnotized, or controlled by demons or evil experimenters, or is dreaming, or that all apparent physical objects are illusions, including desks and pencils. Typically, no one objects to any of these simplifying assumptions and excluded considerations.

Perhaps, by analogy, courts could justifiably take into account only some possible considerations, or only some "test cases," for religious neutrality, while ignoring other relevant considerations or test cases that are nevertheless implausible. Suppose, for example, that a city's religious practice is burdening several entirely imaginary religions, some religions or some extinct or forgotten religions, or even some imaginary religions practiced only on distant planets. Or perhaps religions not practiced locally could be ignored. Perhaps some judges might nonetheless be willing, all else being in order, to say that the city's religious practice is sufficiently neutral under the Religion Clauses. After all, it may not be humanly possible to take into account all of a practice's complex effects on all religions. And there may not be a clear, invariably useful rule telling us precisely which religions are to be considered, and which religions or irreligions may safely be left out of account. ${ }^{154}$

This alternative approach would thus hold open the possibility of increasing the coherence, if not the appeal, of a Religion Clause neutrality analysis by reducing-perhaps radically - the number and variety of religious or irreligious views to be taken into account in assessing any relig-

154. The above analysis is inspired by Professor Walter Sinnott-Armstrong's discussion on moral beliefs as being justified, or not justified, only with regard to some selected and assumedly relevant "contrast class" of alternative moral beliefs. See WALTER SinNotTArmstrong, Moral Skepticisms 251 (2006). As a somewhat related alternative, consider that context may dictate the meaning of "neutrality" just as "flatness" of farmland has a different meaning from "flatness" of a billiard table. See, e.g., Peter Ludlow, Contextualism and the New Linguistic Turn in Epistemology, in CONTEXTUALISM IN PHILOSOPHY II 11 (Gerhard Preyer \& Georg Peter eds., 2005). 
ious practice's neutrality. Perhaps neutrality could gain coherence, if not conviction, in a radically simplified religious universe.

The courts currently engage in something like this "shrinking the universe of test cases" approach when they allow only a narrow, if not parochial, range of religious views to be taken into account. Thus some Ten Commandment cases involve "amalgam[ated]" or combined versions of the Ten Commandments. ${ }^{155}$ One case actually listed eleven commandments. ${ }^{156}$ The explanation for this practice is that the amalgamated version is an attempt-successful or unsuccessful-to neutrally accommodate the beliefs of Protestants, Catholics, and Jews. ${ }^{157}$

Of course, the categories of Protestants, Catholics, and Jews do not exhaust the class of socially important contemporary American religious believers. Any universe-shrinking test for sufficient religious neutrality would need to explain why other prominent categories of believers and non-believers may properly be excluded from the neutrality determination. It is a bit late in the day to bracket all atheists, or all those who reject the Ten Commandments as commandments, as irrelevant outsiders. Even if such an explanation could be presented under the Religion Clauses, it is not clear that such intentional exclusions would be defensible either as meaningfully neutral, or, under an Equal Protection Clause challenge, fair treatment to an excluded group. ${ }^{158}$

More broadly, if the courts were to limit the religions and irreligions that could be accounted for, then the Religion Clause doctrine would be simple and more predictable; but these gains would come at too steep a cost. The values of equality of consideration, intuitive fairness, inclusiveness, and the overall logic and persuasiveness of the opinion would all be sacrificed.

\section{CONCLUSION: AFTER "NEUTRALITY," A SURPRISING ALTERNATIVE}

This article sought to establish first that the idea of "neutrality" in the Religion Clause cases is incoherent. ${ }^{159}$ More importantly, there does not seem to be any viable way to reinterpret, rehabilitate, or otherwise rescue the idea of neutrality in the Religion Clause context. ${ }^{160}$ Some sort of

155. See, e.g., ACLU Neb. Found. v. City of Plattsmouth, 419 F.3d 772, 773 \& n.2 (8th Cir. 2005) (en banc); Books v. City of Elkhart, 235 F.3d 292, 296 (7th Cir. 2000).

156. See $A C L U$ Neb., 419 F.3d at 773 n.2.

157. See id; Green v. Haskell Cnty. Bd. of Comm'rs, 568 F.3d 784, 800-04 (10th Cir. 2009); Books, 235 F.3d at 294 .

158. See, e.g., Susan Gellman \& Susan Looper-Friedman, Thou Shalt Use the Equal Protection Clause For Religion Clause Cases (Not Just the Establishment Clause), 10 U. PA. J. Const. L. 665, 666 (2008) ("[T]he First Amendment clauses are less effective when the problem is neither interference nor true coercion, but unequal treatment."); Bernadette Meyler, The Equal Protection of Free Exercise: Two Approaches and Their History, 47 B.C. L. REv. 275, 339-43 (2006). Equal protection, as well, is often thought to have special value to those most likely to be viewed as marginal, insignificant, or excludable.

159. See supra Parts I-III.

160. See supra Part IV. 
replacement-whether unitary or multi-dimensional-for the idea of neutrality is thus called for.

Perhaps one or more familiar Religion Clause tests, such as the concern for coercion ${ }^{161}$ or for discrimination and inequality, ${ }^{162}$ can be expanded and applied in such a way as to satisfactorily manage the cases typically addressed by the neutrality inquiry. We can hope, but this expansionist project would face already familiar obstacles. ${ }^{163}$

It may be possible, though, to supplement the expansionist project by going much further afield by drawing on conceptually distant areas of the law. In this regard, we might tolerate vagueness and imprecision, as long as we could gain conceptual coherence in Religion Clause jurisprudence.

Religious rights and interests are commonly thought of as qualitatively different from property rights and interests. We will in any event assume this to be true. ${ }^{164}$ But the differences between religious and property rights do not rule out all sensitive, limited use in the Religion Clause area of considerations developed to constitutionally regulate property rights. We might draw on the often murky distinction between the governmental taking of property on the one hand and the mere police power regulation of property on the other. ${ }^{165}$ Dissimilarities will again abound, but it will also remain possible to adapt a number of considerations from the law of takings and police power regulation to the problems commonly addressed by Religion Clause neutrality jurisprudence.

The Religion Clauses are often thought of in terms of prohibitions on certain government actions. In contrast, the Takings Clause admittedly does not prohibit the taking of private property, assuming some public

161. For current problems and limitations associated with coercion tests in the Religion Clause area, see Wright, supra note 21.

162. See sources cited supra note 140.

163. See Wright, supra note 21, at 193-95; sources cited supra note 140.

164. Compare Andrew Koppelman, How Shall I Praise Thee? Brian Leiter On Respect For Religion, 47 SAN Diego L. Rev. 961, 961-62 (2010), with Brian Leiter, Why Tolerate Religion?, 25 Const. Comment. 1, 26-27 (2008). See also Marsh v. Alabama, 326 U.S. 501, 509 (1946) (discussing rights of press and religion in a "preferred position" with respect to property rights).

165. See Lingle v. Chevron, U.S.A. Inc., 544 U.S. 528, 536-38 (2005); Brown v. Legal Found. of Wash., 538 U.S. 216, 233-34 (2003); Tahoe-Sierra Pres. Council v. Tahoe Reg'l Planning Agency, 535 U.S. 302, 321-25 (2002); Palazzolo v. Rhode Island, 533 U.S. 606, 617 (2001); Lucas v. S.C. Coastal Council, 505 U.S. 1003, 1014-16 (1992); Keystone Bituminous Coal Ass'n v. DeBenedictus, 480 U.S. 470, 497 (1987); Penn Cent. Transp. Co. v. City of New York, 438 U.S. 104, 124-26 (1978); Pa. Coal Co. v. Mahon, 260 U.S. 393, 415-16 (1922). While much has changed, doctrinally and otherwise, since 1922, Justice Holmes's majority opinion in Mahon has continued to largely set the most basic terms of the inquiry in distinguishing takings from police power regulation. For scholarly discussion of some of the basic issues, see, for example, D. Benjamin Barros, The Police Power and the Takings Clause, 58 U. Miami L. Rev. 471, 471-73 (2004); Raymond R. Coletta, Reciprocity of Advantage and Regulatory Takings: Toward a New Theory of Takings Jurisprudence, 40 AM. U. L. Rev. 297, 297-303 (1990); Frank I. Michelman, Property, Utility, and Fairness: Comments On the Ethical Foundations of "Just Compensation" Law, 80 HARv. L. Rev. 1165, 1166-72 (1967); Joseph L. Sax, Takings and the Police Power, 74 YALE L.J. 36, 36-38 (1964); Gerald Torres, Taking and Giving: Police Power, Public Value, and Private Right, 26 ENVTL. L. 1, 1-3 (1996). 
use or public purpose, ${ }^{166}$ but rather requires that the deprived party be offered just compensation. ${ }^{167}$ This is only one of many differences between the two bodies of law.

Nor can we argue that the distinction between takings and police power regulation, which we assume to be coherent, is also precisely and clearly defined in all contexts. ${ }^{168} \mathrm{We}$ are seeking, however, not invariably precise guidance, but only some limited, coherent guidance. Even the possibility of some coherent guidance beats an otherwise incoherent standard.

By itself, Justice Holmes's proclamation that "if regulation goes too far it will be recognized as a taking"169 offers only minimal guidance. But it does have the virtue of plausibly claiming that a constitutional violation may be a matter of excess rather than a dramatic qualitative change in policy. And importantly, it may well be even by itself a coherent claim, unlike claims to religious neutrality. So by analogy, a hypothetical judge might say that if a government policy in the Religion Clause area goes "too far," it may violate one or both of the Religion Clauses. Such a claim might well be, by itself, relatively illuminating, but it would also be coherent, and thus an upgrade over our incoherent neutrality jurisprudence.

Can the police-power-versus-takings case law offer any more useful guidance, by analogy, in the Religion Clause area? Is a "too far" test as good as we can do? Actually, at least some further coherent guidance seems possible. Of course, we cannot expect that a currently vague jurisprudence of the police power and takings will miraculously transform itself into precise, detailed, and convincing guidance in the Religion Clause area. But again, any plausible, coherent guidance would improve the jurisprudence.

And in fact, the takings-versus-police-power case law does have something more to offer. At least at a general level, the takings-versus-policepower cases commonly take explicitly into account a number of factors relevant to and potentially useful within Religion Clause jurisprudence. Let us consider four such factors. These four would include the following: first, the actual effects of the government policy or practice on those persons claiming a Religion Clause violation; ${ }^{170}$ second, any relevant, rea-

166. See, e.g., Kelo v. City of New London, 545 U.S. 469 (2005); Haw. Housing Auth. v. Midkiff, 467 U.S. 229 (1984). Of course, it would oversimplify the Free Exercise Clause jurisprudence to see it as a flat, absolute prohibition of government actions. See, e.g., Emp't Div., Dep't of Human Res. v. Smith, 494 U.S. 872, 879 (1990) (providing the basic test).

167. See Brown, 538 U.S. at 235 (citing Williamson Cnty. Reg'l Planning Comm'n v. Hamilton Bank of Johnson City, 473 U.S. 172, 194 (1985)).

168. See, e.g., Tahoe-Sierra, 535 U.S. at 326 (quoting Lucas, 505 U.S. at 1015); Sax, supra note 165, at 37 (noting the Court's now ritual disclaimer "that 'no rigid rules' or 'set formula' are available to determine where regulation ends and taking begins").

169. Mahon, 260 U.S. at 415.

170. See, e.g., Lingle, 544 U.S. at 539; Palazzolo, 533 U.S. at 617; Mahon, 260 U.S. at 413. 
sonable expectations of an adversely affected person; ${ }^{171}$ third, the "character" of the government's policy or practice, ${ }^{172}$ including any actual hostility toward a religion or irreligion; and fourth, any sense that a legitimate governmental goal, benefitting a broad class of persons, is being pursued at the expense of one or a few heavily burdened victims, rather than more fairly at the expense of the broader public receiving the benefit. ${ }^{173}$

Each of these four factors seems readily translatable, with clear relevance and fairness, to many Religion Clause contexts. To oversimplify, each of the four factors above seeks to address some particular aspect of the "severity of the burden" 174 imposed by the government policy on the objecting party. Of course, fairly assessing the burden on an aggrieved party, in any context, will pose judicial challenges. Offering only the fair market value of condemned property ${ }^{175}$ may undercompensate an owner who must pay attorneys' fees, or who endures uprooting or the stress of a forced move, let alone any genuine lifestyle or sentimental value costs. Undercompensation and insensitivity in any legal area should generally be avoided. So a Religion Clause court drawing from the takings-versuspolice-power case law should be especially aware of the constitutional value of even largely symbolic, brief, socially stigmatic, or dignity-based nonpecuniary injuries in the Religion Clause context. ${ }^{176}$ The logic of the takings-versus-police-power distinction is thus useful here as well. ${ }^{177}$

The takings-versus-police-power cases are, finally, of use in setting some lower bounds to the sorts of religious injuries for which compensation, let alone an injunction, will be appropriate. The idea of a "reciprocity of advantage" 178 is relevant. When a plaintiff complains of some effects of religious policy that a court concludes are offset or counterbalanced-not just diluted - by the same or other relevant religious policies so that the plaintiff suffers no net injury, the takings-versus-police-power cases sensibly suggest that no compensation-let alone an injunction-is

171. See, e.g., Lingle, 544 U.S. at 539; Palazzolo, 533 U.S. at 617; Penn Central, 438 U.S. at 124 .

172. See, e.g., Lingle, 544 U.S. at 539; Palazzolo, 533 U.S. at 617; Penn Central, 438 U.S. at 124 .

173. See, e.g., Lingle, 544 U.S. at 539; Palazzolo, 533 U.S. at 618; Mahon, 260 U.S. at 415-16; Coletta, supra note 165 , at 302-03.

174. Lingle, 544 U.S. at 539; see also Mahon, 260 U.S. at 413.

175. See, e.g., United States v. Reynolds, 397 U.S. 14, 15-18 (1970); City of New York v. Sage, 239 U.S. 57, 61 (1915).

176. Many Establishment Clause or Free Exercise Clause cases, in which the plaintiff has standing, rely largely on claims of these sorts of injuries as distinct from genuine pecuniary losses. See, e.g., Van Orden v. Perry, 545 U.S. 677, 694 (2005) (Ten Commandments monument on state capitol grounds); McCreary Cnty. v. ACLU, 545 U.S. 844, 859-61 (2005) (courthouse Ten Commandments posting, as supplemented by other displayed items).

177. See the discussion of "demoralization costs" in Michelman, supra note 165, at 1213-17. See also Torres, supra note 165, at 16 (discussing Michelman on demoralization costs in the takings-versus-police-power regulation context).

178. See, e.g., Keystone Bituminous Coal Ass'n v. DeBenedictis, 480 U.S. at 491 \& n.20 (1987). For scholarship supporting the idea of a broad scope for noncompensable police power regulations, see Barros, supra note 165, at 472-73; Coletta, supra note 165, at 303. 
due. ${ }^{179}$ This condition is less likely to be met by any ignored or marginalized religious position. Nor should this condition be applied in a way that ignores or underemphasizes socially stigmatic and other related injuries of a religious sort. ${ }^{180}$

In sum, the case law distinguishing takings from police power regulations is of surprising use in plausibly addressing the sorts of Religion Clause issues currently addressed incoherently through the concept of neutrality. Of course, some modifications of the takings and police power law will be required. And that body of law cannot possibly resolve all the relevant Religion Clause cases in some unequivocal and universally persuasive way. But as a matter of law and of logic, any reasonable alternative beats the inescapable incoherence of Religion Clause neutralism.

179. See sources cited supra note 177; Mahon, 260 U.S. at 413 ("Government hardly could go on if to some extent values incident to property could not be diminished without paying for every such change in the general law."); Michelman, supra note 165, at 1165 , 1214-18. By analogy, a dominant religious group's complaints should not be heard when a marginalized religious or irreligious group is temporarily acknowledged by the government in some transient, pro forma, inconsequential, entirely symbolic, or noninvidious way.

180. See sources cited supra note 176; see also, e.g., Stone v. Graham, 449 U.S. 39, 42 (1980) 
